\title{
Lag Screw Technique for Treating a Mandibular Angle Fracture: Case Report
}

\author{
Técnica con Tornillo de Tracción para el Tratamiento de \\ Fractura de Ángulo Mandibular: Reporte de Caso
}

\author{
Gabriela Mayrink*; Marcelo Breno Meneses Mendes*; Roger William Fernandes Moreira*; \\ Ferdinando de Conto** \& Renato Sawazaki*
}

MAYRINK, G.; MENDES, M. B. M.; MOREIRA, R. W. F.; DE CONTO, F. \& SAWAZAKI, R. Lag Screw Technique for treating a mandibular angle fracture: case report. Int. J. Med. Surg. Sci., 1(3):263-267, 2014.

SUMMARY: The treatment of mandibular angle fractures involves several postsurgical complications and is in greater demand when compared to therapeutic approaches for other types of mandibular fractures. Such postsurgical complications as bleeding, swelling, infection, dehiscence, pseudoarthrosis and paresthesia might affect individuals in both sexes and at all age groups. The presence of a mandibular third molar, a cross-sectional area thinner than the tooth-bearing region, and biomechanical forces might hamper the surgery, making it longer and more complex. Internal fixation is aimed at undisturbed healing under condition of functional and without any period of intermaxillary fixation. Adequate fixation depends on different fracture types, patients' general health and compliance, and the timing of the operation. This case report involves a mandibular angle fracture successfully treated with the lag screw technique, a simple approach to treat one of the most common fractures involving the mandible, quickly restoring the patient's oral functions.

KEY WORDS: Jaw fixation techniques; Jaw fractures; Mandibular injuries.

\section{INTRODUCTION}

Mandibular angle fractures are relatively common and account for 30 percent of all types of mandibular fractures reported in the literature. Treatment involves either a conservative or surgical approach, with the latter being more frequently required due to the need for surgical materials to repair the fracture.

Among the surgical techniques are four main mandibular fixation methods: (a) use of two miniplates (one in the tension and the other in the compression zone) in cases of displaced fractures or associated with other mandibular fractures; (b) the Champy technique, using one or two miniplates in the alveolar region of the mandibular angle (neutral zone); (c) use of a reconstruction plate in the compression zone for patients with poor adherence to treatment and in cases of sequelae fractures or infections; and (d) fixation using the lag screw techinque. Those fixation modes described at $a, b$, and $c$ should follow Association for Osteosynthesis/ Association for the Study of Internal Fixation (AO/ASIF) recommendations.

The aim of this article was to report a mandibular angle fracture case successfully treated with the lag screw technique and to highlight some important points about this therapeutic approach.

\section{CASE REPORT}

This report includes a male individual, aged 29 years, victim of physical aggression (punch on the face two days prior to treatment), and

* Division of Oral and Maxillofacial Surgery, State University of Campinas, Piracicaba, Brazil.

** Division of Anatomy and Morphology, University of Passo Fundo, Passo Fundo, Brazil. 
treated at the emergency clinic of São Vicente de Paulo Hospital, Passo Fundo, RS. The patient presented with pain and swelling on the right side of his mandible.

During oral examination, good dental hygiene, no missing tooth, and Class I occlusion were observed. No malocclusion was detected. Palpation revealed some mobility in the mandibular right angle.

A mandibular right angle fracture, with a linear presentation and little displacement, was confirmed through radiographic images (Fig. 1).

Considering the good occlusion conditions and the fracture's little displacement, a surgical mandibular fracture reduction was made and the lag screw technique was used for fixation of the mandibular segments.

An intraoral access in the right retromolar region and mucoperiosteal detachment were made as the patient was under general anesthesia. Just as recommended in the original technique, two long drills, one $2.7 \mathrm{~mm}$ and another $2.0 \mathrm{~mm}$ in diameter, were used to bore holes in the mandibular segments. The drill should be adequately positioned to avoid damage to the inferior alveolar bundle and, at the same time, to find areas with adequate bone thickness (Fig. 2). Therefore, the drill was positioned at an angle of approximately 20 degrees and about 12 to $15 \mathrm{~mm}$ below the fracture. The $2.7 \mathrm{~mm}$ drill was operated in a superior-inferior direction up to the fracture line. At this moment, it is indispensable that

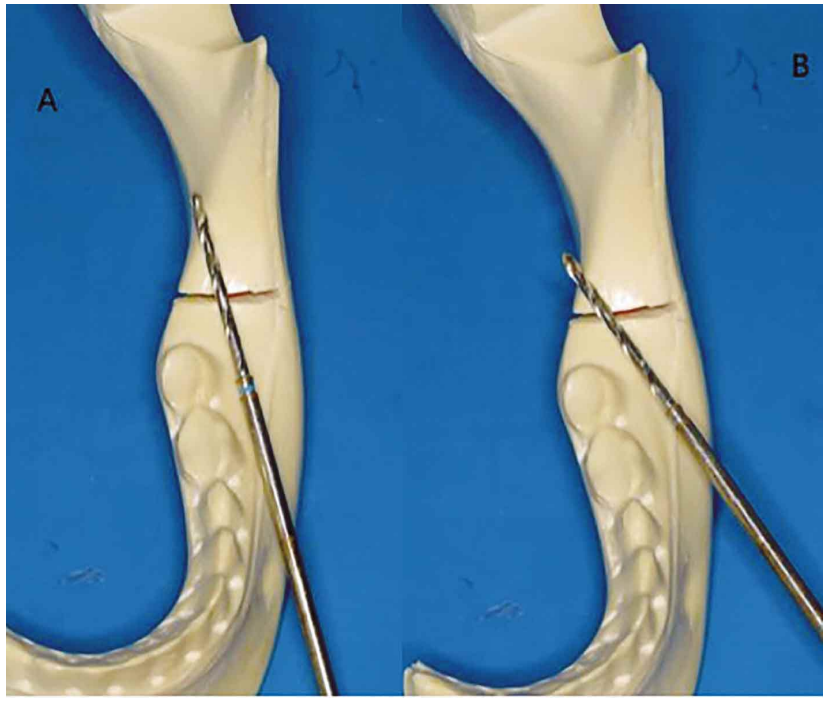

Fig. 2. Scheme showing the right positioning of the drill (A) and the wrong one (B) in this last one, the remaining lingual bony is minimum for support the masticatory load.
Fig. 1. Preoperative radiography showing linear fracture mandibular left angle.

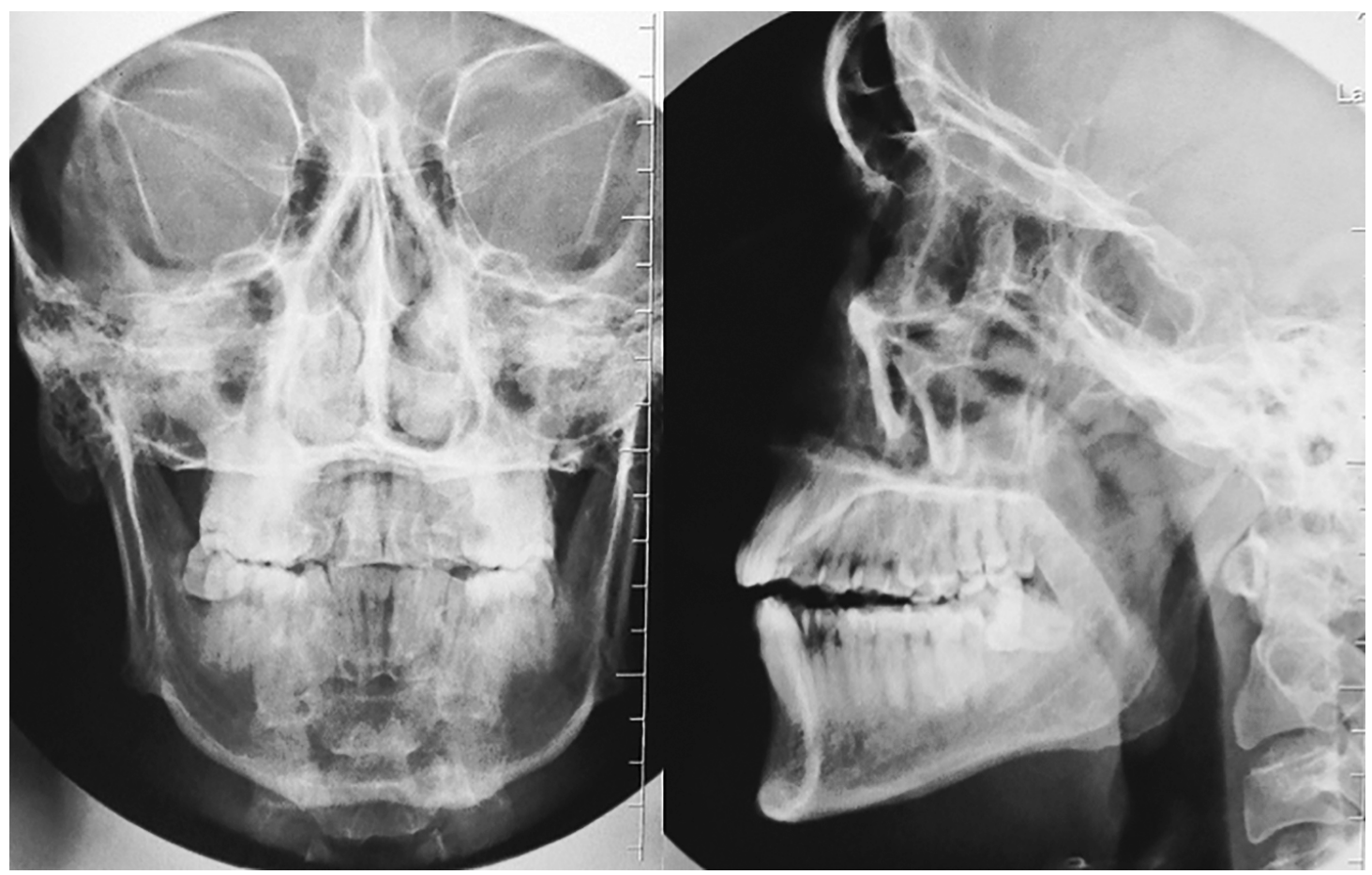


the segments be held in position, since any movement might alter the second drilling positioning, leading to a technique failure (Fig. 3).

The second drill $(2.0 \mathrm{~mm})$ was operated up to the lingual cortex of the distal segment. A long screw (18 mm length) was used to

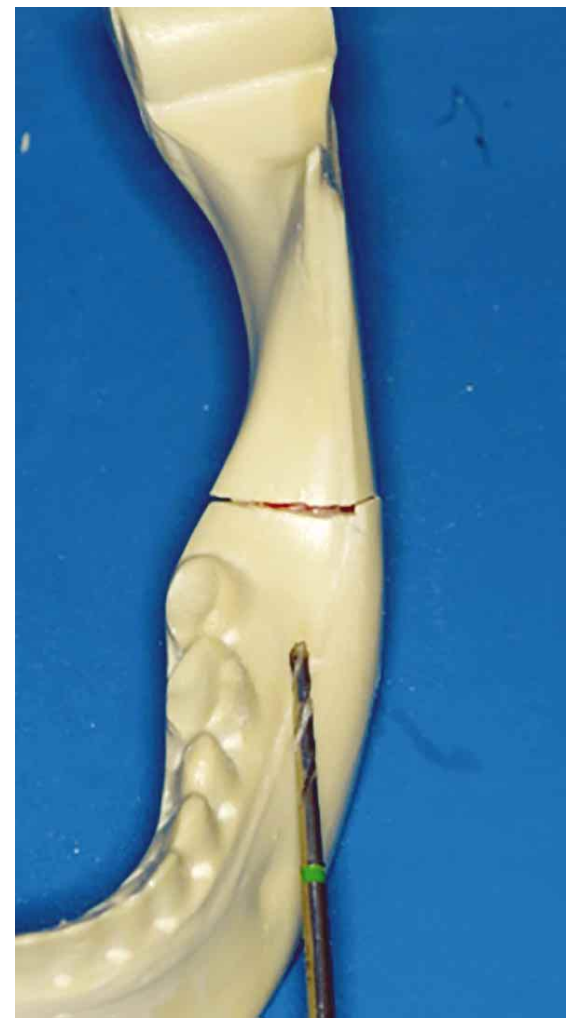

Fig. 3. Scheme showing the perforation with the first drill (2.7 $\mathrm{mm}$ ) until the fracture line. tighten the distal and proximal segments together (Fig. 4).

Maxillomandibular blockade during or after surgery was not needed. The fixation stability and occlusion were checked. Re-absorbable suture was used and the patient was discharged on the same day of surgery (Fig. 5).

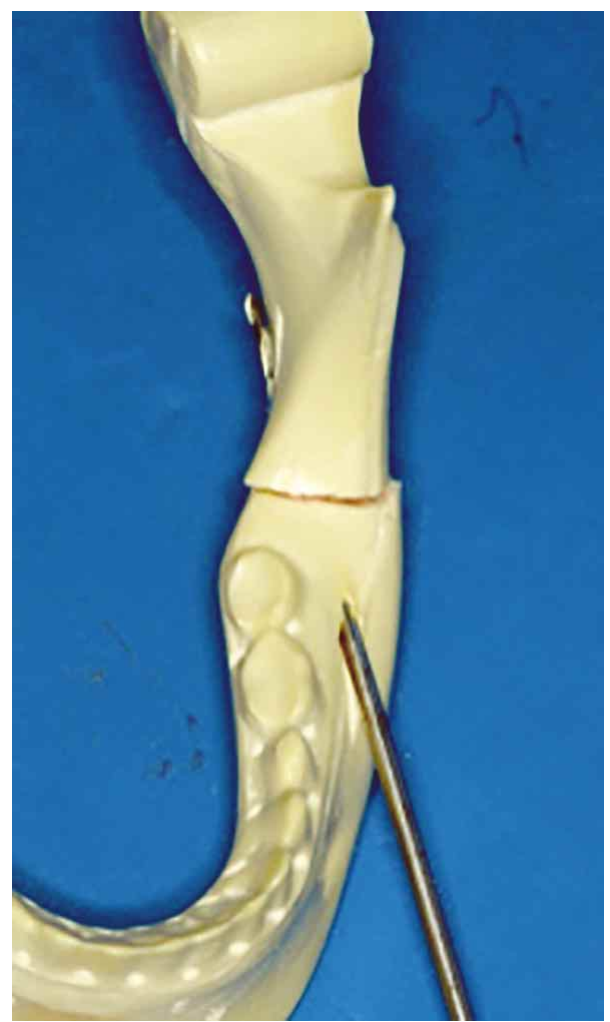

Fig. 4. Scheme showing the perforation with the second drill $(2.0 \mathrm{~mm})$ until the lingual cortex.

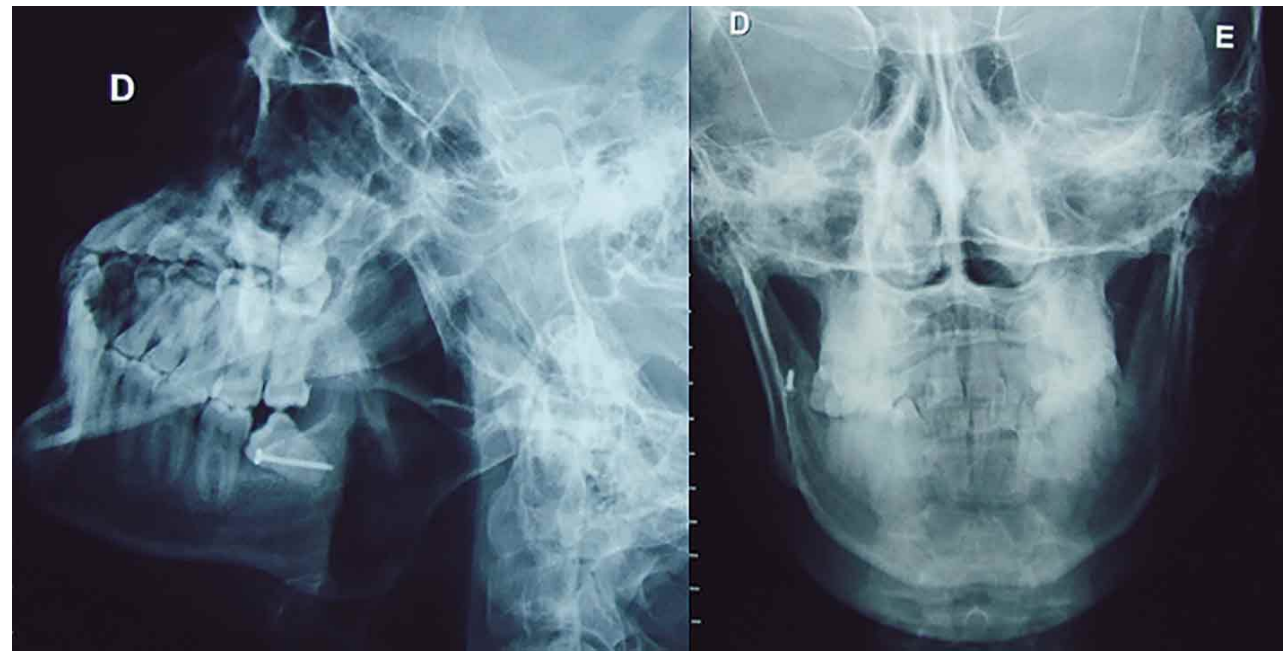

Fig. 5. Postoperative radiography evidencing the good fracture reduction, using only one compression screw. 


\section{DISCUSSION}

The lag screw technique for mandibular angle fixation was recommended by Niederdellman, in 1981, such as an alternative to using miniplates to treat fractures (Niederdellmann et al., 1981). The lag screw principles are based on the compression of bone fragments - the screw compresses the proximal against the distal fragment as it is inserted into the hole.

The bony fragment compression works in the regeneration initial period, sharing the load between the screw and the segment. Therefore, reducing the segments is mandatory.

Initially, the technique was proposed using the intraoral access by fixing the fracture with a long screw (18 to $25 \mathrm{~mm}$ long), which might be inserted using a trocart (Murr et al., 2002). Certainly, the screw installation is facilitated when the trocart is used, since the screw must be in an angulation of about 10 to $20 \mathrm{~mm}$ in relation to the buccal cortex (Ellis \& Ghali, 1991). However, in cases with little displacement and depending on the surgeon experience, the extra oral access for the screw installation should be avoided to keep up with a good angulation (Farris \& Dierks, 1992).

Among the technique advantages are its low cost (only one screw is needed), reliability, primary bone repair, and reduced surgical time (20 minutes, approximately). However, this technique is not recommended in cases of comminuted fractures, once the compression might cause fragment displacement and shortening of the fractured segments, leading to some type of malocclusion.

In our case report, the third molar was absent; however, this is no contraindication for the technique used. According to Niederdellmann \& Shetty (1987), the third molar must be left in the fracture line unless it shows great mobility or is associated with some pathological process. If its removal is needed, it must be done before or at the same time of screw removal (Prein, 1998).
Maintaining the tooth would provide a wider area for fragments to be in contact. In this case report, the patience had an included mesioangular third molar, without pathology signs associated. This one was held in position and caused no interference with the fracture's reduction and fixation.

The main disadvantage of this technique is the fact that the screw might be tightened in an area with little bone quantity. Therefore, an incorrect screw installation might lead to a technique failure (Schaaf et al., 2011).

A previous study comparing the lag screw technique with the use of miniplates for fixation of a mandibular angle revealed that the lag screw technique provided the best fracture reduction, with a smaller "gap" between the segments, a positive result since there is a direct relationship between the repair process and the space between the fractured segments. If the "gap" is bigger than $2 \mathrm{~mm}$, therepair process might be delayed (Schaaf et al.).

Shetty \& Caputo (1992), through a biomechanical study, reported that a lag screw alone in tension zone might provide enough stability to resist the function forces applied in the mandible.

There are several methods to treat mandibular fractures. The lag screw technique as a therapeutic approach towards any mandibular fracture involves inherent postoperative complications, such as infection and malocclusion. Our article exemplified the successful treatment of a mandibular angle fracture using a simple and low cost technique.

\section{CONCLUSION}

The lag screw technique is effective, simple, reliable and inexpensive and can be indicated for patients presenting linear fractures in the mandibular angle. 
MAYRINK, G.; MENDES, M. B. M.; MOREIRA, R. W. F.; DE CONTO, F. \& SAWAZAKI, R. Técnica con tornillo de tracción para el tratamiento de fractura de ángulo mandibular: reporte de caso. Int. J. Med. Surg. Sci., 1(3):263-267, 2014.

RESUMEN: El tratamiento de las fracturas de ángulo mandibular se relaciona con diversas complicaciones postquirúrgicas y tiene mayores demandas en comparación a los enfoques terapéuticos necesarios para otros tipos de fracturas mandibulares. Complicaciones postquirúrgicas como sangrado, inflamación, infección, dehiscencia, pseudoartrosis y parestesia podrían afectar a individuos de ambos sexos y en todos los grupos de edad. La presencia de un tercer molar mandibular, un área de sección transversal más delgada que la zona de los dientes de soporte, y las fuerzas biomecánicas podrían obstaculizar la cirugía, haciéndola más larga y compleja. La fijación interna está dirigida a una cicatrización sin alterar las condiciones de funcionamiento y sin períodos de fijación maxilo-mandibular. La fijación adecuada depende de los diferentes tipos de fractura, la salud general de los pacientes y el tiempo quirúrgico. Se reporta el caso de una fractura de ángulo mandibular tratada con éxito con la técnica de tornillo de tracción, un enfoque simple para tratar una de las fracturas más comunes relacionadas con la mandíbula, y restaurar rápidamente las funciones orales del paciente.

PALABRAS CLAVE: Técnicas de fijación de la mandíbula; Fracturas de la mandíbula; Lesiones mandibulares.

\section{REFERENCES}

Ellis, E. 3rd. \& Ghali, G. E. Lag screw fixation of mandibular angle fractures. J. Oral Maxillofac. Surg., 49(3):234-43, 1991.

Farris, P. E. \& Dierks, E. J. Single oblique lag screw fixation of mandibular angle fractures. Laryngoscope, 102(9):1070-2, 1992.

Murr, A. H. Operative techniques: Innovations in facial trauma. Alternative techniques of fixation for mandibular angle fractures. $O p$. Tech. Otolaryngol. Head Neck Surg., 13(4):273-6, 2002.

Niederdellmann, H.; Akuomoa-Boateng, E. \& Uhlig, G. Lag-screw osteosynthesis: a new procedure for treating fractures of the mandibular angle. J. Oral Surg., 39(12):93840, 1981.

Niederdellmann, H. \& Shetty, V. Solitary lag screw osteosynthesis in the treatment of fractures of the angle of the mandible: a retrospective study. Plast. Reconstr. Surg., 80(1):68-74, 1987.

Prein, J. Manual of Internal Fixation in the Cranio-Facial Skeleton. Techniques recommended by the AO/ASIF Maxillofacial Group. Heidelberg, Springer, 1998.
Schaaf, H.; Kaubruegge, S.; Streckbein, P.; Wilbrand, J. F. ; Kerkmann, H. \& Howaldt, H. P. Comparison of miniplate versus lag-screw osteosynthesis for fractures of the mandibular angle. Oral Surg. Oral Med. Oral Pathol. Oral Radiol. Endod., 111(1):34-40, 2011.

Shetty, V. \& Caputo, A. Biomechanical validation of the solitary lag screw technique for reducing mandibular angle fractures. J. Oral Maxillofac. Surg., 50(6):603-7, 1992.

Correspondence to:

Marcelo Breno M. Mendes

Faculdade de Odontologia de Piracicaba

Av. Limeira, 901

Bairro Areião

CEP 13.414-903

BRAZIL

Email: marcelobreno@yahoo.com.br

Received: 07-08-2014

Accepted: 11-09-2014 